\title{
Evaluating the engagement of universities in capacity building for sustainable development in local communities
}

\author{
Chris Shiel ${ }^{\text {a }}$, Walter Leal Filho ${ }^{\mathrm{b}, *}$, Arminda do Pac, $\mathrm{o}^{\mathrm{c}}$, Luciana Brandli ${ }^{\mathrm{d}}$ \\ a FacultyofScienceandTechnology,BournemouthUniversity,DorsetBH125BB,UK b ResearchandTransferCentre "ApplicationsofLifeSciences" \\ Hamburg/HamburgUniversityof AppliedSciences,LohbrueggerKirchstraße65, \\ 21033Hamburg,Germany \\ c UniversityofBeiraInterior,DepartamentofBusinessandEconomics,EstradadoSineiros/n,6200-209Covilhã,Portugal d PassoFundo \\ UniversityMestradoemEngenhariaCivileAmbiental,Brazil
}

Keywords:

Capacitybuilding

University

Sustainabledevelopment Community
ABSTRACT

Universities have the potential toplaya leading role inenabling communities todevelop more sustainableways ofliving and working however, sustainable communities may only emerge with facilitation, community learning and continual efforts to build their capacities.Elementsofprogramme

Planning and evaluation on the onehand, andcapacitybuildingontheother, areneeded. Thelatter entailsapproachesandprocesses that may contribute to community empowerment; universities may either lead such approaches, or be key partners inanendeavour to empowercommunities to address the challenges posed by the need forsustainable development. Although capacity building and the promotionofsustainabledevelopment locally, areontheagenda foruniversities whotakeseriously regionalengagement, verylittle is published that illustrates or describes the various forms of activities that take place. Further, there is a paucity of studies that have evaluated theworkperformedby universitiesinbuildingcapacityforsustainabledevelopmentatthelocallevel.Thispaperisanattempt to address this need, and entails an empirical study based on a sample of universities in the United Kingdom, Germany, Portugal and Brazil. Thepaperexamines the extent to whichcapacitybuilding for sustainable development is beingundertaken, suggests the forms thatthismighttakeandevaluates someofthebenefitsforlocalcommunities. Thepaperconcludesbyreinforcingthatuniversitieshavea criticalroletoplayincommunitydevelopment; thatrolehastoprioritisethesustainabilityagenda.
1. Introduction

The quest for fostering capacity building for sustainable development at universities isnotnew, although as thispaperwill argue systematic evaluation of initiatives and programmeplanning maybe either lacking, or ad hoc. As early as 1999 for instance, the Association of University Leaders for a SustainableFuture (ULSF) indicated a variety of areas in which universities could be involved in sustainable development (e.g. management, planning, development, research, operations, purchasing, transportation, design, new construction, renovation, communityserviceandoutreach education, orcapacitybuilding)(ULSF, 1999in van Weenen, 2000). Today, capacity building activities are focused on twomain areas: activities towards building capacity among students and staff towards a moresustainableuniversityandcampus(with training onmatterssuchasenergy efficiency, the reduction of waste and $\mathrm{CO}_{2}$ emissions) and externally-oriented activities aimed at building capacity within a local community, to promote sustainable developmentamongstawidergroupofstakeholders. Thelatter isthe matterofinterestandfocusofthispaper.

One of the main documents encouraging university-community cooperation is the "University Charter for Sustainable Development" produced by COPERNICUS. The document points out ' “. . u universities' duty to propagate environmentalliteracyandto promotethepracticeofenvironmentalethicsinsociety, in accordance with the principles set out in the Magna Charta of European Universities...andalongthelinesoftheUNCED recommendationsforenvironment anddevelopmenteducation
...'.TheCharterasksuniversities "...tocommitthemselvestoan on-goingprocessof informing, educating and mobilising all the relevant parts of society concerning the consequencesofecological degradation...'(CRE-Copernicus, 1994).

The original Copernicus document was signed by about 300 European higher educationinstitutions(HEIs),confirming theircommitmenttotheimplementationof sustainability conceptswithintheirownuniversities(UniversityofRostock, 2014).

Today, most of the activities in the university-community nexus fall within two main areas: educational collaborative models for environmental and sustainability education, and the implementation of projects to identify and promote sustainable andeconomicdevelopmentinacommunity. Thesetwoissuesmay beexploredinturn.

Interms of collaborativemodels for environmental and sustainability education, the community provides the context of the learning environment and may play a central role in the learning process. Through community engagement, students can experience first-hand the inter-connections between environmental issues and develop their understanding of how individuals and communities interact. Furthermore, communitysitesprovideideal locations forclassprojects, appliedand service learning, and internships (Schmitz, Stinson, \& James, 2010), whereas academic institutions, asmembersofthecommunity, arecoretoeducating citizens, professionals, innovators, andproblem-solvers.

In such circumstances universities may further the co-creation of community change by contributing with research, technical skills, human resources, and emerging knowledge. The various Faculties at a given university could offer theoretical, research, and technical knowledge, that would usefully support community membersindesigningandimplementingprojects(Schmitzetal., 2010). Universities committed to community engagement might establish reciprocal partnerships that could improve the creativity and responsiveness of both (Boyer, 1996inSchmitzetal.,2010) 
As far as the implementation of projects to identify and promote sustainable and economic development isconcerned, a wholecommunity approach isneeded, which requires the participation of a variety of organisations and/or the establishment of alliances at the local level. The key constituencies and strategic themes of the partnership may be reflected in a community engagement strategy. In order to succeed, theyneedtoengagethefollowing stakeholders:

Local people, whoresidenearaUniversityorCollege, witha particularfocus on the areawithina10-20-mileradius;

Local governmentandregionalbodies; locallybasedvoluntaryand charitableorganisations; localandregionalbusiness.

Strategic elements that would catalyse the promotion and enhancement of capacitybuildingforsustainabledevelopmentata communitylevelincludeenabling university facilities tobeused byavarietyofstakeholderssuchasthepublicandlocal schools, andprovidinguniversitysupportforlocalactivitiesandpartnerships, which mightrepresenta moveaway from the 'Ivory Tower' cliche', to asituation wherethe university'scontributionis appreciatedbyabroaderrangeofstakeholders.

Exemplifyinghow this worksin practice, theUniversity of Rostock(Germany), which is a signatory of the COPERNICUSCharta (University of Rostock, 2014), establishedsometimeagoa workingteamtitled"Agenda21"todevelopcommunity based capacity building strategies on sustainable development in the following fields:

Coordination of existing Agenda 21-activities at the University of Rostock and interlinkingwithrelatedactivitiesinRostockcity andregion.

Support for sustainable development in the region via knowledge and technology transferand.

Support of and contribution to additional partnerships with urban and regional institutions.

Activities thatwereimplementedinclude:

The organisation and implementation of exhibitionson the topicsSustainability andAgenda21 withregionalpartners

Organisationandimplementationofconferencesorsymposia- conferenceseries

"TheUniversityofRostockasactivepartnerof municipalitiesandregionsfora sustainabledevelopment" and

Contributiontourbanandregionalworkingteamstowardsthe LocalAgenda21.

However, theaboveillustrationappearstobeanexception ratherthanthenorm, analysisofavailableinformationand publishedreportsshowsthatdespitethefact thatarangeof activitiesaimedatincreasingthepotentialofuniversitiesto engage with capacity building for sustainable development in communities exists, their frequencyisstillratherlimited. Thereis a" processesbywhich highereducationinstitutionsestablishandsustaincommunity partnership" (Hart, Northmore, Gerhardt, \& Rodriguez, 2009, p. 45). The subsequent parts of this paper will seek to explore this trend, outline the situation andproposewhatneedstohappenasa consequence.

\section{Capacitybuildinganduniversities:theneedforresearch}

Theglobalissuesandchallengesfacinghumanity(population growth,climate change, technological developments, and economic globalization, for example) are extensivelyreferred to in the literature. Theimpacts of currentproduction and consumption patterns, resource scarcity, growing inequality, and changes in politicalandenvironmentaldynamics(UnitedNations, 2012) underscoretheneed tobuildcapacity formoresustainable development(SD)and tofosterthecreation ofsustainable communitiesandasustainablesociety.

Ifthegoalistoachievesustainabledevelopment, thencapacity buildingisseen asoneofthemainwaysofworkingtowardsthat achievement(UNEP,2002).Thisis explicit in the various declarations on sustainability for higher education, where the importance of learning, communication, and also capacity building for sustainable development (Lozano, Lukman, Lozano, Huisingh, \& Lambrechts, 2011; Moore, 2005; Tilbury, 2012) is repeatedly confirmed and writ large. Building capacity for sustainable developmentin education is also one of the key areas within the international implementation scheme for the United Nations Decade of Education for Sustainable Development (O'Rafferty, Curtis, \& O'Connor, 2014). Universities have an important role in contributing to sustainable development through educating their students and preparing them to addressthechallenges; theyalso needtobuildcapacitywithintheirownstructures and systems so that they operate more sustainably and, finally, they have a role to play externally by contributing (through education and research) to building capacitywithstakeholdersacrosstheircommunities.

According to the WRI (2008) building capacity in local communities is becomingmorecriticalinaglobalworld, where resourcesarebecomingscarceand methods and technologies are changing. Merino, Carmenado, and de los (2012) emphasise that building capacity through the community contributes not only to social development, but also to economic growth. These arguments support the need for research that explores how higher education institutions (HEIs) are workingwithintheircommunitiesintermsofbuildingcapacitiesforsustainability, butalsoto showadvancesandwaysforward.

However, capacity building is not an easy concept (Brown, LaFond, \& Macintyre,2001)andisthus, challengingtoresearch.Spoth, Greenberg,Bierman, and Redmond (2004)define capacity-building as the efforts designed to achieve andcoordinatefinancial,human (time,knowledge,skills), technical(equipment, accessto databases, datamanagement,materials)andotherresources (e.g.space, facilities, leadership support) directed towards "quality implementation of evidence based, competence-building interventions through public education deliverysystems"'(p.32). Brownetal.(2001)considerthat capacitybuildingisa continuous process of improvement within an institution with the goal of maintaining or improving the services provided, i.e., an internal process, which may be enhanced when an external entity assists the institution to improve its functions. Capacitybuilding is a multidimensional conceptdescribed interms of its components, strategies, dimensions, or interventions; outcomes may also be unpredictable - during the learning process several planned and unplanned experiencesandactivitiescanoccur(Brownetal., 2001).

A literature review shows that the term "capacity building" has received increasing interest over the last few years. Some of the studies have focused on definition (Thomas \& Day, 2014); other researches have tried to map different interventions (Davison et al., 2014); and a few studies have explored their achievements

(O'Raffertyetal.,2014).

Furthermore, there is a paucity of studies that have evaluated the work performed byuniversitiesinbuildingcapacity for sustainabledevelopmentat the local level, or which have involved communities at large (Leal Filho, 2010; Nicolaides, 2006). Tilbury (2011)argues (in relationtoprogrammeevaluations) thatthereis alack ofmeta-analysisstudiesorlongitudinalresearchthat provides conclusively evaluations of the effectiveness of universities' engagement in education for sustainabledevelopment(ESD) perse. Thereis aneed to showhow universities can build capacities within communities but according to Tilbury (2011), whilethereisanabundanceofinformationavailableaboutESD processes andlearningonspecificprojects, generallythesearenot documentedinsufficient detail.Thereisalackofdatathatshows howobjectivesandoutcomesareachieved.

In the scope of university engagement with capacity building in the community, there are some obvious areas where action is evidenced, including service-learning, mentoring, support to elderly people (e.g. University of the ThirdAge),communityarts, andenvironmentandhealth.Eachinvolvesdifferent types of collaborations with different methodologies employed (Northmore \& Hart,2011).

Hart etal. (2009) studied the example of Brighton University where specific programmes relating to capacity building are underway in the community. This university has a CUPP (Community-University Partnership Programme) that providesa servicethatisdevelopingandpromotingengagementactivities across theuniversityand sustainablepartnerships, with theaim of providingalong-term benefit to local communities and to the university. However, in this example the activities aremorerelated to thearea ofhealth and socialcapacitybuilding, rather than local economic development. Nevertheless according to these authors, universitystructurestosystematicallyarticulateandsupport capacitybuildingare stillrelativelyrare in the UK(United Kingdom); in Americanuniversities (witha longhistoryof "service learning") andinAustralianuniversities, suchstructures aremore developed. 
Giventheimportanceof"engagement"and "impact"agendas, universities across the world have been incorporating civic participation and community service into their research and teaching in various ways. However universities havehad some difficulties indemonstrating theadded value that theybring when addressing complex social problems in partnership with local communities (Northmore \& Hart, 2011). Additionally, despite the increase of practical and academic activity in the field of university-community engagement, there is a relative lack of research focused on the processes by which universities establish andmaintaincommunitypartnerships(Hartetal.,2009).

Sometimes there is afailuretoaligntheinstitutionalneeds with theneedsoflocal communities and what in fact happens is that most engagement is focused on either providing students with experiences in the community, or providing university expertise to the community, with less focus given to the benefits that increase from giving members of the community access to a university (Hart et al., 2009) or that accrueasaresultofcollaborations. Asa solutiontosomeoftheproblems, Alter(2005) suggests that what isrequired is the developmentof "enablingplatforms" thatserve to bring community-based experience and academic study together to develop profound mutual understanding - essentially what is required is greater dialogue betweentheuniversityandthe communityitserves(oroughttoserve).

Other problems relate to the difficulties encountered in evaluations of programmes. The concept of capacitybuilding is intangible. The literaturepresents several definitions and arguments for why capacity building is important, but discussesless thequestionofhowtomeasurecapacitybeforeorafterthe intervention; measures to evaluate improved capacity (Brown et al., 2001) may be poorly articulated.AccordingtoNorthmore andHart(2011)itiseasiertomeasuretheresults of occasional collaborative projects, but it is a longer term perspective that is more likelytoimproveboththequalityandimpactofcommunityuniversitypartnerships.

Shriberg (2002) suggests that to measure sustainability in highereducation, it is necessary to develop criteria for crossinstitutional assessment. He questions the possibility thatanalysts shoulddevelopa “universaltool" toassesssustainabilityin higher education. Such a tool might have benefits in terms of engagement comparisons, however, there is no agreement over whether such an approach is necessarytogatherandshareknowledge.

As Berke and Conroy (2000) noted in their study, many communities are implementing the concept of sustainability, but theirplannersmayhave onlyabasic understanding of how to translate it into practice, and usually do not take a holistic approach toguidingdevelopmentandmovingtowardssustainability, focusingonthe morepracticalaspects of communitylife. Thus, given the challenges involved in the construction, implementation and evaluation of partnership activities, Northmore and Hart (2011) argue that it is crucial to develop more theoretical models of sustainability that draw on the experience of sustainable partnership working; existingmodelsareeitherinsufficiently explicativeorincomplete.

Basedontheperceivedneedsseenfrom theliterature, this paperdiscussesthegap between theory and praxis of current social learning towards sustainable development in the contexts researched. It also attempts to highlight what might encourage collaboration and foster learning opportunities which contribute to furthering sustainable development. Thepaper will draw upon examples from four differentcountriesandasanexploratory study, willofferanopportunitytoassesswhat the sampled universities are doing to build capacity in their local communities, to illustrate the range of projects and approaches, and the extent of evaluation. Within thisscenario, itispossibletobegintoprovidea comparativeandevaluativeoverview, to suggest effective processes for building capacity for sustainability, as well as highlightingthechallenges.

\section{EvaluatingUniversities'engagement}

Theevaluation ofuniversities'engagementincapacitybuilding took the formof desk based research, a survey of academic communities who are engaged in taking forward sustainable development within higher education, and furthere-mails and telephoneinterviews with participantswhoresponded. The focus waslargelybased ontheUKbutthenextendedtodetermineifthe UKresponsewastypical.

The approach used in this paper is to bring an overview from countries with different particularities in terms of local sustainability and consequent demand for building capacities with regard to different HEIs. The work entails samples of universitiesinthree EU(EuropeanUnion)countries(UK, GermanyandPortugal)as well asa Latin American country, Brazil, allowing foridentification of similarities andcontrasts.

The rationale behind this sampling is based on threemainfactors:

These countries were selected in part for convenience (the authors' countries of residence).

The sample lent itself to a consideration of the issues that might reflect the different stagesofengagementincapacitybuildingfor sustainabledevelopmentaround the world.Forinstance, the UK haspioneeredsustainabledevelopmentwithinhigher education with policy development and initiatives across the sector. Germany is amongst the most advanced countries in respect of sustainable development policies and implementation. Apart from strong government emphasis on sustainability, theGerman populationischaracterisedbyquitehighenvironmental awareness,providingafertilegroundforstudiesandresearch relatedtoSD.Brazilis one of the world's largest developing countries and its sustainable development policieshaveevolved inthelastfewyears.Brazilalsohostedimportantconferences relatedtothefutureofsustainabledevelopment(Rio92and Rio+20)makingBrazil a country where interest in sustainable development is likely to be high and increasing.

Theplurality and diversity of experiences in the foursampled countries offer useful insights into the dynamics of sustainability inahighereducationcontext.

The aim and line of thinking adopted by the authors was not to have a representative sample within each country, but to gain responses from as many institutions as possible, based on willingness to participate (a convenience sample). Therefore, it wasanticipated that thelevelofresponseanddepthofthe descriptionof the case studies elicited might vary, although attempts were made to elicit as much responseaspossible.

Ineachcountrytheresearcherssentthequestionstoseveral institutionssoliciting theirinvolvement. Although thesurvey is notrepresentativeit does, combined with the review of the literature, contribute to building a rough profile of the status of capacity building in each country. Initially to get a feel for the state of play within the UK, an email was sent out via 'SHED-SHARE' (a community network operated through "jiscmail.ac.uk" that comprisesmembersworkingacrosstheUKsectoron SD). Participantswereaskedtorespondtothefollowingquestions:

1. Could you share any examples of work in the community that your University is doing to build capacity for sustainability - i.e. how are you developing a sustainablecommunity?

2. Haveyouevaluatedyourbuildingcapacityworkandwhat measuresyouhaveused forimpact?

3. Is building capacity for sustainability in the local community part of a coherent over-archingUniversitywidestrategy?

4. Inrelationtothelatter(point3)thehunchisthatmanyindividual academicswillbe undertaking individual projects but few universities will have a strategy for buildingasustainable communityaspartoftheirlocal/regionalstrategy.Isthisthe case?

Emailswerealso sent to colleagues at otheruniversities. Although almost thirty UK institutionsweretargetedonlynine respondents fromUKinstitutionsprovided full comments on the questions. As several respondents suggested talking to the NationalUnion of Students(NUS), who have been co-ordinating capacity building activitiesacrosshighereducation(withinthe UK), thesamequestionswerealsoposed to the NUS. Similar questions were then posed to institutions in Germany, Portugal andBrazil;ineach countryalmosttwiceasmanyinstitutionswere contacted thanthe total responding with an aim of getting a comparable sample to the UK; eliciting responses was more challenging and thus, the number of institutions finally representedfromthesecountries, issmaller(seeTable1).

\section{Responses from the UK}

Theresponses wereenthusiasticandoftenlisted(andmany "show-cased")a range of projects that universities were undertaking. General observations and examplesofresponsesfromnine institutionsarepresented.

Many initiatives featured student volunteering in the community, student projects (applied and research) and student internships. Overall there is strong 
evidencethatuniversitiesareactively encouragingtheirstudentstoparticipateina rangeoflocal campaignsrelated toactivitiesthatfallunderthebroadumbrella of sustainable development, from students helping local business in audits of their sustainabilitycredentials(UniversityofSouthampton,forexample)to "cleanup" campaigns and local conservation projects. Although not all respondents evidenced student volunteering, several of those that did, referred to the link betweentheintroductionofstudentcommunityengagement programmesandthe development of employability skills. It might be argued that the need to enhance "employabilityskills" within theUK(anagendareinforcedbyGovernment)has beenagreater driverforstudentvolunteering,thanthemotivetobuild sustainable communitiesquiteoftensuchvolunteeringactivities couldfallunderthebannerof building capacity for sustainable development but are not explicitly acknowledgedassuch.

Several respondents were from institutions that are either known for their sustainability credentials (through the People \& Planet, Green League table), or had recently taken part in the Higher Education Academy's "Green Academy", (see Luna \& Maxey, 2013), as such their responses often included links to their strategicplanswheretheiruniversities'sustainabledevelopment ambitionswere clearly articulated; some of these strategy documents referred to sustainable communitiesbutgenerally (beyondaboldambition), providedlittledetailonhow theywould

Table1

Universitiesinvolvedinthestudy.

\begin{tabular}{|c|c|c|}
\hline Country & $\begin{array}{l}\text { Numberof } \\
\text { universities }\end{array}$ & Universities \\
\hline UK & 9+NUS & $\begin{array}{l}\text { UniversityofSouthampton,Bournemouth } \\
\text { University,PlymouthUniversity,Gloucester } \\
\text { University,EdinburghUniversity, Worcester University, } \\
\text { DeMontfortUniversity,University ofWalesTrinitySt } \\
\text { David,Manchester University,NationalUnionof } \\
\text { Students }\end{array}$ \\
\hline Germany & 5 & $\begin{array}{l}\text { HamburgUniversityofAppliedSciences, } \\
\text { LeuphanaUniversity,UniversityofBremen, University } \\
\text { ofKiel,UniversityofHannover }\end{array}$ \\
\hline Portugal & 5 & $\begin{array}{l}\text { UniversityofLisbon,UniversityofBeira } \\
\text { Interior,InstituteofHighStudiesofFafe, } \\
\text { PolytechnicInstituteofGuarda,Polytechnic Instituteof } \\
\text { Porto }\end{array}$ \\
\hline Brazil & 5 & $\begin{array}{l}\text { UniversityofSa oPaulo,PassoFundoUniversity, Federal } \\
\text { UniversityofRioGrandedoSul,Federal } \\
\text { UniversityFluminense,State } \\
\text { UniversityofRoraima }\end{array}$ \\
\hline
\end{tabular}

build capacity, or evaluate such. The University of Worcester's Strategic Plan 2013-2018, for example, includes as an area of distinction that they will seek to "promote principles of sustainability in their broadest sense. Through our teaching, research and knowledge exchange activities we will promote sustainable communities, services, businesses and theuse of physical resources. We will foster a culture that values sustainability in arts and culture and promote socialenterpriseinthe region"'(UniversityofWorcester,n.a).

The Director of Environmental Sustainability at Worcester outlined several practical community initiatives and highlighted a number of collaborative community projects, the most notable being "The Hive" - a joint public and University library which houses fiveservices within a very sustainable building. Other examples included recycling and behaviour change campaigns with the CityCouncilandintheCity,CountyCouncilenergy projects, "WorcesterEnergy Pioneers", "Energise Worcester", and the "Our SpaceYourPlace" enterprise competition. They also work closely with the "Local Enterprise Partnership" (LEP), where environmental sustainability is a cross cutting theme and they are developingtheconceptofsocialsustainability.

As far as "monitoring" endeavours, work is "at an earlystage of developing metrics to measure the impact on the community"; they are also developing metricstoevaluatetheirdigital publishingproject "www.susthingsout.com" asa vehicle for bringing together academics, expert practitioners, students and the communitywhichalso supportsteaching, learning and researchinsustainability (Raghubansie,Corbett,Boom,\&Weaver, 2015).
AresponsefromtheUniversityofGloucester(aninstitution consistentlyhigh intheGreenLeague)providedarangeof illustrativeexamplesofbuildingcapacity forsustainabilityinthe community. Theseincluded:

“ $10,000 \mathrm{~h}$ Campaign' - recorded 10,000 h of voluntary community service by studentsandstaffinlocalcommunities

$25+$ yearsofdistancelearning coursesincommunitydevelopment(CD)tomainly part-timestudentsscatteredaround EnglandandWales-1000+gradsengaged inworkingwith communitiesinpublicandvoluntarysectors

Publications and action research with \& for local communities around aspects of sustainability-internships, placements, live projectassignments, community andgraduatescontributing backintoteaching;latestresearchfundingisfocused on studentslearningfromrealworldexposure/projects,etc."

Theirevaluationofcapacitybuildingrangesfromrecording "voluntaryhours input to community and the sustainability service to local communities, and the nature of that volunteering e.g. charitable trustees, teaching youth how to play soccer,etc."

They also noted in their response: "Individual module evaluations and assignments-recordingstudentinternships andimpacts; dissertations related to livesustainability/communitytopics" and, suggestedthattherewas "alotmoreto add'”.

Inresponsetothequestionofcoordinationoftheendeavouras partofacoherent over-arching University strategy, they referred to various sections of their “'StrategicPlan2012-17',(Universityof Gloucester2014)whichstates “'Weare dedicated tocreating sustainablefuturesacross thecommunitiesweserve"'(p.7) and that they will "Support the activities of the United Nations University RegionalCentreofExpertisein Sustainabilitytobuild strongpartnershipsacross the Severn region"' (p. 16). There is a staff member responsible for outreach activitiesandtheir ambitionsinthisareaareembeddedintheUniversity'sstrategic planaswellastheirSustainabilityStrategy. "Activitiesand progressarediscussed and interrogated annually, via the Sustainable Development Committee and reportedintheUniversity'sannualreport".

It might be expected that those universities who are UNU accredited Regional CentresofExpertise(RCE)inESDwill undoubtedlybedoingmoretobuildcapacitytheirpurpose is tofocus on theengagementand capacitybuilding of stakeholders in theregions theyserve. RCEisanetwork of existing formal,non formalandinformal educationorganisations,mobilisedtodeliver ESDtolocalandregionalcommunities (see Wade,2013). RCEs aspired to achieve the goals of the UNDecade ofEducation for SustainableDevelopment(DESD,2005-2014), bytranslatingthe objectivesinto thelocalcommunitycontextinwhichtheyare situated.The“"RCESevern" facilitates workshopsandseminarsas wellasconvenesdiscussiongroupsandstaffandstudent placements with the 110 organisations which formpartofthis consortium. Itisoneof sixactiveRCEsintheUK.

In terms of their impact some are critical, Scott (2012), for example, comments negatively on RCEs "All rather disappointing, given that they promised so muchespecially to themselves" however their potential for the development and mobilisation of communities working towards sustainability is quite clear (Wade, 2013) and although little impact has been felt in the UK, that may not be the case elsewhere.

A respondent from Edinburgh University commented on the history of the university'sengagementinsustainabilityexternally:

"As long ago as the late 1990s members of the University of Edinburgh contributed to and participated in a Lord Provost's Commission on Sustainable Development; since then the University has been represented on theEdinburgh Sustainable DevelopmentPartnership-oneofsevenPartnershipbodies under the framework of the Community Planning Partnership which subsumed the LA21 mechanisms"'. However it was also suggested that such bodies might be perceivedas "meretalking shops" thatmaynothave" reallygainedanytraction forthe sustainabilityagenda".

The respondent agreed that "there will be many academic and support staff colleagues whoquietlyserveinmanydifferentways - possiblymoreon thenational stage than local community" although it was "difficult to identify appropriate metrics". Someof thewaysthatindividualacademicsandstaffmakeacontribution to building capacity is further expanded by Higgins, Nicol, Somervell, and Bownes 
(2013,pp.200-202)butisgeneralrather thanspecific, andreinforcesthat whilethere maybemanyareasof engagement, theyarelargelyad-hoc.

At the University of Manchester a "Living Lab" (University of Manchester, 2014) approach aims to contribute to, "developing the University of Manchester campus as a site for applied teaching and research around sustainability and low carbon" (http:// universitylivinglab.org). Their website provides "a platform for collaboration between researchers, students, external stakeholders and the Directorate of Estates and Facilities to deploy and monitor new technologies and servicesinrealworldsettings", andalthoughit isnotyetsubstantiallypopulated, the project has produced an Interim Report (University of Manchester, 2013). A respondent from Manchester University suggested that the University records the number of employees serving on School Boards as a measure of community contributionunder "Social Responsibility". Thesamerespondentcommentedthatit might be interesting to "compare HE to FE, as latter has much greater implicit obligationtorespondtolocalneeds" whichperhaps carriestheconnotationthatsome higher education institutions might be less responsive to local needs than Further Education.

PlymouthUniversityresponded that(despitetheinstitution beingconsistentlyin thetopthreeoftheGreenLeague)therewas "notanoverarchingviewofcommunity projectsspecifically relatedto worktobuildcapacityforsustainablecommunities". Therewerehoweveracoupleofrecentprojectsthatmightbe considered:

Plymouth Growing Futures - is an innovation in sustainability education. The Project Coordinator has led a number of collaborative curriculum projects between university students and community groups, using the Physic Garden and spaces around campus as learning resources for sustainability learning. Projects include Social Work students working with local learning disability service users, and 3D DesignstudentsworkingwithPlymouthinBloom communitygrouptocreateapublic gardenspaceinthecity.

The Listening Post - an initiative from the Student Counselling and Personal Development Service thathasengaged members of thelocalUniversity of the Third Age to train as volunteers listeners for any student wanting an immediate drop-in listening service. Research is being conducted through this project into the links betweenpersonalwell-beingandsustainableandresilient communities.

Although there was no formal collation of community projects, "Plymouth had conducted a "Sustainability in the Curriculum Review" in 2012, where one of the questions asked Programme Leaders about the extent of community partnerships in their programmes".

An exceptionally detailed response was provided from the University of Wales TrinitySaintDavid(UWTSD)whereitisquite obviousthatsustainabledevelopment is a driving ambition central to planning. Although Education for Sustainable Development and Global Citizens has been compulsory in Wales since 2006, UWTSD since 2012, has established "The Institute of Sustainable Practice, InnovationandResourceEffectiveness(INSPIRE)', andhassought togofurtherthan many institutions in centralising this endeavour. The University's Strategic Plan articulates the vision: "The University will have an equally important role in advocating global citizenship and education for sustainable development" (University of Wales, 2013, p. 1). The institution had made "a commitment to contributing to sustainability in the region and through partnership aims to provide strong community leadership for sustainable development in Carmarthenshire; a pledge between the University and Carmarthenshire County Council has been drafted. Capacity building will be centrally coordinated but monitoring and evaluationevidenceisindevelopment".

At Bournemouth University (BU) capacity building has included a variety of innovativeprojects, manyledbyindividualacademics, othersledbylocalbodiessuch as Bournemouth Borough Council, the County Council, local schools and the Local Enterprise Partnership that have included university membership. A significant project has been work with the Bournemouth Borough Council (the only UK local authority to have endorsed the Earth Charter) to implement the Earth Charter Principles and to embed these across council operations and within the community (see Bournemouth Borough Council, 2014). This work has been led by a steering group that has included university membership. Projects have included a "symposium on air travel" (with a particular focus on the "Bournemouth Air Festival"), re-generation, community cohesion activities, recycling, transport planning,perma-culture, andseveralothers. Theimpactofsuchworkhasbeenlargely qualitativelyevaluatedwiththeobviousexceptionofworktogain "FairtradeTown" status (chaired by an academic), where accreditation requires more quantitative measures.

AcademicsatBUhavealsoundertakenappliedresearch particularlyintheareasof conservation, ecology, forestryand themarineaspects oftheenvironment, although most of this has not been centrally co-ordinated and has arisen out of individual interests and opportunities for funding. The "Poole and Purbeck Portal" http://www.pooleandpurbeckportal.co.uk/news/servesas acommunityrepository that connects students, staffand community but has not been evaluated. The most recentproject involvestheUniversity working withlocalstakeholdersaspartof the "Bournemouth and Poole Sustainable Food City" project. The latter has been Universitysponsoredandassuchismorecentrally coordinated with thedirectaimof capacity building. However the project is still struggling to articulate appropriate evaluation measures.Capacitybuildingoverallisnotmonitoredcentrally withinthe University.

Within the UK, a big driver and contributor to capacity building has been the NationalUnionofStudents(NUS)whichdeservesa mention. Thestudentbodyhas beeninstrumentalindriving changeandengaging withcapacitybuildingprojects within their institutions and within the broader community. The NUS runs a number of sustainability opportunities for students outside of their university/collegecampus. Thishasincluded:

“Supportingstudents'unionstohaveapositiveimpactontheir localcommunities, facilitating everything from wildlife garden creation in schools to providing recycledcomputersandIT trainingforlocalunemployedpeople.

Utilising behaviour change programmes developed in HE/FE in off-campus settings, enabling widespread engagement with the sustainability agenda in hospitals, charities, fire stations, police stations, museums, shops, schools etc. whilstprovidingvolunteeringopportunities forstudentstoaddcapacitytothese organisations and programmes (sometimes these voluntary opportunities are partoftheircurriculum).

Supporting research projects for students into the feasibility of new projects, the impactsofexistingprojects, analysisof methodologiesused,etc.

Encouragingknowledgetransferbetweenorganisationsrunning sustainabilitywork inlocalcommunities."'

A respondent from theNUS stated “'Obviously the Student's Union is not an FHEIbut it is part of our longer term strategy to continue and expand this workenablingstudents'unionsto becomegreenhubsintheircommunities,normalising sustainability, and creating graduates who leave education with the skills, tools, knowledgeandcommitmenttosustainabilitythatwill enablethemtobepartofthe future solution to sustainability rather than continuing to being part of the problem". Evaluations of projects, for example "Green Impact" are usually undertaken through surveys thatare "generallybased on reflections of what has workedwell, andwhathasn't, abouttheirparticipationinthe programme".

Finally, a respondent from De Montfort University where sustainability is a central feature of University Strategy, suggested that there is "little in the way of systematic process for incorporating it into the 'culture' or 'fabric' of the organisation; whenthisdoesoccurthereisverymuchanenvironmentalfocus and littleexplicitattentionpaidtocapacity".

Therespondentwentontoagreethatitislikelythatmany individualacademics willbeundertakingindividualprojectsbut fewuniversitieswillhaveastrategyfor building a sustainable community as part of their local/regional strategy. Suggested hurdles for building capacity for sustainable development and evaluatinguniversities' contributionstosuchwereidentifiedas:

"An environmental rather than a holistic vision of sustainability. Physical and proceduralboundaries betweenHEandits environment-foranumberofreasons e.g.wherestafflive.

Environmental sustainability becomes less central where there are competing economicpriorities.

Sustainabilityisseenasaproduct-outcomeratherthana process; thisistoalarge extentaproblemgeneratedby academicsandresearchers.

Other competencies for contributing to sustainability appear under other bannerse.g.socialandhumancapital,economic capital,etc." 


\section{Responses from Germany}

Thesystematicimplementation of sustainabilityatGerman universitieshasa rathershorttradition, withmanyadhoc initiativestakingplaceinarecentpast.This is because of the fact that, prior to the late 1990s, the emphasis was not on sustainability, but on environmental conservation and environmental protection at universities. The line of thinking adopted then, was that as large organisations, universities had to become more environmentally friendly. The Association of Rectors of German Universities (HRK) started in 1996 a scheme titled "Environmental Protection at Universities", whose emphasis was on the use of environmental management systems at higher education institutions to reduce energyconsumption, handle wastesandusewaterresourcesmorerationally.

In 1997, a ground breaking event was organised at the University of Luneburg(thepreviousnameoftheLeuphana University), congregatingmanyof those universities in Germany whohadan interest on elements of environmental management on the one hand, and sustainability on the other, to present their initiativesandexchangeexperiences. Theeventsubsequentlyled toapublication titled "Environmental Conservation and Sustainability at German Universities: Concepts and Implementation" (Leal Filho, 1998), which opened the way for furtherworkinthis field.

Anintensificationofeffortstowardsmakingsustainabilitymore prominentin German universities occurred after; actions were often associated with operations, and less with curriculum and research, although the trend has progressivelychanged. The firstexample of a formal and long-terminstitutional commitment was given by the Hochschule Zittau-Go"rlitz, situated at the easternmostpartof Germany, whichin1999becamethefirstGermaninstitutionof higher education having successfully undergone the full cycle of EMS requirements - including validation and registration - as specified in the EC regulation1836/93(EMAS)whichistheEuropean equivalentoftheinternational ISO 14001 standard. Particular concern in Zittau was shown for the active involvement and participation of students and employees during all individual phases of the environmental management system (Delakowitz \& Hoffmann, 2000).

Since then, many German universities have joined the sustainability movement, and have been very active in respect of the introduction of sustainability at the institutional level, in operations, teaching, research (or a combination of all) in various ways and formats. There is now a vibrant sustainability scene in Germany, whose size was exemplified by the nearly two hundred delegateswhoattendedaseminaronsustainabilityatuniversities, called by the German Councilon Sustainable Development (Rat für Nachhaltigkeit)a non-governmental organisation, set up to provide advice to the German governmentonmattersrelatedto sustainabledevelopment.

The survey that was undertaken as part of this paperstarted from the premise that,eventhoughmanyuniversitiesengagein sustainabilityinonewayoranother, itwouldbedifficulttogather responsesfromthem; quiteoftenthepeoplewhomay beableto provideinformationshowlittleinterestintakingpartinsuch studies.

The goal was to gain responses from a sample of 10 universities in northern Germany(tomatchtheUKresponse).Onlyfive institutionsresponded:Hamburg University of Applied Sciences (Hamburg), Leuphana University (Lüneburg), University of Bremen (Bremen), University of Kiel (Kiel) and University of Hannover. Theyformthebasisofthisanalysis. Anadditionalexplanation for the limitedlevelofresponsesobtainedisthefactthatacertain amountofsurveyfatigue exists within German Institutions. As a result, many staffs are not interested in participatinginsurveys, onlythemostmotivatedtendtorespond.

Whenaskedtoshareanyexamplesofworkinthecommunity thattheirUniversity is undertaking to build capacity for sustainability (i.e. how are they developing a sustainablecommunity), the LeuphanaUniversity(formerUniversityofLu"neburg) responded by stating that students at the first semester (from all disciplines) participate together in seminars that are trans-disciplinary and work together with local communities on relevant challenges. Topics might be "bicycle lanes, communityparticipation, exchanges on politicalissuessuchasmigrationissuesand others".

Other examples are trans-disciplinary research initiatives where for instance a sustainability assessment approach was developed together with a local fruit juice producerandabakery, toimprovetheirsustainabilityperformance.HAWHamburg replied that its sustainability projects all involve local stakeholders and the communityatlarge, whoareinvitedtobecomepartnersor associateswithitsprojects. The rationale here is that, by means of an inclusive approach, members of the local community, and especially but not only NGOs, are able to benefit from the projects and take advantage of the capacity building works performed as part of them. HannoverUniversitystated thatitoccasionallyoffers trainingand furthereducation activitiestargetedtolocal organisations, whereastheuniversitiesinBremenandKiel stated theyonlyhaveadhocapproacheswhichinvolvecapacitybuilding atthelocal level.

Inrespect of whether theyhave evaluated theirbuilding capacitywork, and what measurestheyhaveusedtomeasuretheir impact, theLeuphanaUniversitystatedthat there is a longitudinal study that has been running for several years investigating the capacitydevelopmentamongstudentsinthefieldsofsustainable development.

Thishashowevernocommunity focus. HAWHamburg, inturn, processesfeedback fromparticipants fromitsactivities, and is henceabletokeepanaccuraterecord oftheeffectivenessofthe trainingitoffers. AtKielUniversitythereseemstobenoreal emphasis on measuring impacts, but this aspect is important at the University of Hannover, where records of the training initiatives are kept, partly because it is a requirement from funding bodies. In Bremen the emphasis is on the level of satisfactionofattendees, whoareregardedascustomers.

Asfarasbuildingcapacityforsustainabilityinthelocal communityisconcerned, and whether this part of a coherent overarching University wide strategy, all universitiesprovidedaclear yes.

It is worth noting that theactivities performed bythesampled universitiesmostly focusonurbancommunitiesandsettings.It appearsthatonlyatHAWHamburgandat theLeuphanathe structuresthroughwhichcommunitycapacitycanbeenhanced, are beingatleastpartlyexplored. Andinnoneofthemwereserious considerationsgivento thenatures of the partnerships involved between local governments, communities, anduniversities themselves. Theseareregarded asimportant, but thereseemstobeno evidenceofasystematicapproachtowardsthem.

\section{ResponsesfromPortugal}

InseekingtoevaluatecapacitybuildingfurtherinEurope, responseswereelicited from five universities in Portugal; the lack of responses might be explained by the reality that Portugal has lagged behind other EU countries in relation to sustainable developmentwithnationallevelstrategies andengagementnot emerging until2006 (Shiel\& Pac,o, 2012). As theresponseswere verylimitedandlackedthedescriptive detailthatrespondents gavefromtheUKtheyaresummarisedandpresentedin Table 2. Securing responses was particularly challenging because for the most part, the institutionsdidnotevenunderstandthe natureofthequestions-inpartthisisreflective of the policy contextatanational levelbutalsobecause theactivities of Portuguese universities in capacitybuilding in local communities havemore traditionallybeen relatedtoentrepreneurshipand knowledgetransfer.

The results show that occasionally the institutions who responded are making someeffortstobuildsustainablerelations inthecommunity, butsucheffortsmightbe considered minimal and largely not strategically planned. Compared to the UK students unionshaveonlyjuststartedworkingforthecommunityin Portugal.

\section{ResponsesfromBrazil}

Theimplementation of sustainabilityinBrazilianuniversities doesnotcompare with the European universities (Leal Filho, 2010) nor with North American universities (Barlett \& Chase, 2013). Although there are some examples of engagement thatcouldbe cited and an evidentevolution of the themein recentyears, initiatives are still largely ad-hoc. Sustainability actions are isolated and sometimes guided by ideologies, resulting from teachers, students and staff projects (Brandli, Leal Fillho, Frandoloso, Korf, \& Daris, 2015). This scenario (a lack of institutional approaches to sustainability) sets the context for the results in relation to capacity buildinginBrazilianuniversities.

Theanalysesperformed in Brazil, was based on fiveuniversities, althoughtwice asmanywerecontactedtotakepart.Mostofthe initiatives tobuildcapacityarein the area of education and involve the development of new skills and experiences to support more sustainable forms of development. The University of Sa o Paulo recordedthefollowingprojects: 
Development and dissemination of educational publications for solid waste managementandenvironmentaleducation;

Table2

SynthesisoftheresponsesfromPortugueseHEI

$\begin{array}{ll}\text { Institution } & \begin{array}{l}\text { 1.ExamplesofworkinthecommunitythatyourUniversity isdoingtobuild } \\ \text { capacityforsustainability }\end{array}\end{array}$

Un.Lisbon

-Projectaiming tocollectnon-perishable food supplies and distribute them amongstSolidarityInstitutions

UBI

$$
\begin{aligned}
& \text { - Healthscreeningandtreatmentprogrammesinseveral villagesofthe } \\
& \text { region } \\
& \text { - PromotionofactivitiesrelatedtoPublicHealth.E.g.active ageing } \\
& \text { programmeswiththemunicipality,sexeducational projectswiththe } \\
& \text { schools } \\
& \text { - Organisingstudents'volunteeringforinstitutions -Projectaimingto } \\
& \text { promotesportingactivitiestogetthe developmentofsocialcapital.Some } \\
& \text { actionsweredirected tochildrenwhoareinfostercareandchildren } \\
& \text { attendingthe primaryschool } \\
& \text { - Supporttoentrepreneurshipeducationprogrammes implementation } \\
& \text { insecondaryschools }
\end{aligned}
$$

$\begin{array}{ll}\text { IESF(Fafe) } & \text { - Consultancyforsmallbusinesses } \\ \text { IPG } & \text { - Help in the creation and certification of a brand to promote the regional } \\ & \text { products } \\ \text { IPP } & \text { - Workshop organisation for people with disabilities (help blind people to } \\ & \text { findajob) }\end{array}$

Preparation and publication of technical and scientific materials about wildlife management in urban areas, sustainability in the curriculum, research and extensionintheuniversity;

Extension projects in environmentaleducation and composting in public schools in localcommunity;

Training of environmental leadership among the employees of the universityprogramaimstocapacityenvironmentally 17,000technicalandadministrative staff(2012-2015);

Courses for the external community in environmental education and composting areas.

Other examples were also cited by the remaining universities surveyed: training for correct destination and rational use of medicines; education and citizenship, training in managing finances, professional training in information technology and waste management, projects in local knowledge and practices related to agriculture, food and craft. The Federal University Fluminense responded by stating they have specific courses with emphasis on sustainability, such as a masters degree and $\mathrm{PhD}$. The building capacity work in this university is concentrated on developing their students and their professional performance (ratherthancommunityengagementthatfallsoutsideofthe institution).

TheStateUniversityofRoraimastated thatactionsinbuilding capacityinvolve " community quality of life (indigenous and fishermen), collective health and preservation of the environment (water quality, solid waste management, constructionofseptic system, separationoforganicandinorganicmaterials, useof naturalcompostforsoilfertilisation, ecotourism)',

There are also capacity building projects to support economic development and changes tolocalpractices. Aresponse from University ofPassoFundoshows projectsindifferentareas:

"Assistancetocooperativesthesolidwastemanagement;

Supporttopublicuseinconservationunits;

Developmentofsustainableregionaltourism;

Supporttoimplementationcleanerproductioninsmallorganisations;

Supporttoproductionofbiodieselwithusedoil', .

The FederalUniversity ofRioGrande do Sulgavetwoexamples ofcapacity

building with impacts in economyand wellbeing community. One of them is the supportforagroupofwomenfrom theIslandofPintadawhomakecraftswithscales

and fishleather asincomegeneration, helpingtodevelopnewproductstosell. The second, a project for development of social and educational activities with communitiesandteamsfromtheIslandofPintada andCruzeirodoSul. Theproject enables the community to plant garden crops, to use these plants for therapeutic purposesand involvesexchangeofinformationabouthumanhealth.

There are projects with the intention of providing services to the local

\section{Haveyouevaluated your \\ buildingcapacity work?}

No

No

$\begin{array}{ll}\text { No } & \text { No } \\ \text { No } & \text { No } \\ \text { No } & \text { No }\end{array}$

No
3.Isbuildingcapacityfor

sustainabilityinthelocal community

partofacoherent over-arching

Universitywidestrategy?

Yes.Theyplanannuallysome activitiesandareinvolvedina network aimingtodevelop socialand environmental solutionsfor community

community, for example, in relation to health assistance like dentistry, physiotherapy forvisuallyimpaired, motoractivities forautistic, physicalfitness forhealthyliving. All theseprojects haveinvolvement of studentsallowing them putintopractice whattheylearn. Thepossibilitytoworkwithcommunityprovide capacitiesforstudentsnotonlyinthetechnicalway, butalsothe abilitytodealwitha range of real situations and contexts and develop other capabilities like problem solving, communication, ethical values and other range personal attributes. Furthermore, thecommunitybenefits, especiallypoorfamilies.

In relation to the evaluation of building capacity work, and measures used to assesstheimpacttheuniversitiesstated that thereisnotaninstitutionalevaluation. However, the State University of Roraima commented that some projects have parameters, criteria and indicators that contribute to evaluating whether the proposedobjectiveswereachieved.Also, the UniversityofPassoreported theuse of participatory methodology, action research, specific measures for projects results(e.g.kg. recycledwaste)andperceptionofbehaviourchanges.

Insummary, theprojectsundertakenbytheuniversities involvedaretheresult of individual initiatives and do not emanate from a university wide strategic approach; theconcern is with local initiatives with a specialist focus, that address theneedsof particularcommunities.

\section{Discussion}

Much of the literature on capacity building relates to health and social care, community development and social cohesion rather than building capacity for sustainabledevelopmentwithinlocal communities. Therearehowevernumerous projects and examples of case-studies across the HE sector in the UK, Portugal, Germany and in Brazil, thatsuggest that universities are developing a variety of actions within their local communities to enhance sustainability, as well as undertaking research for local stakeholders that will undoubtedly contribute to capacitybuilding,astheexamples capturedforthispaperdemonstrate.

However, asobserved, theextenttowhichuniversitiesare engagedincapacity building forsustainabledevelopmentwithin localcommunitiesis stillsomewhat patchy and not uniform across the world, or even in Europe. In comparison to the other countries explored in this study, the UK sample demonstrates greater advancement with capacity building projects specifically related to sustainable developmentand this has beensupported by the activities of theNUS. In contrast, 


\begin{tabular}{ll} 
Factors & Implications \\
\hline $\begin{array}{l}\text { Stafftraining-staffaretrainedforeducationandresearch, trainingin } \\
\text { partnershipworkandcapacitybuildingneeds tobeprovided }\end{array}$ & Impactsthepotentialtoscaleuplocalengagementandcapacitybuildingprocesses \\
$\begin{array}{l}\text { Localrelationshipsbetweenpartsoftheuniversity/individual academicsand } \\
\text { multiplestakeholdersarevariousandneed tobemapped }\end{array}$ & Betteraccess/communicationwithstakeholders;lessadhocactivity,duplicateefforts andtime-wasting \\
$\begin{array}{l}\text { Needsassessment } \\
\begin{array}{l}\text { Evaluationtools-areunder-developedornon-existent } \\
\text { Existenceoflocalchampions }\end{array}\end{array}$ & WithoutafullneedsassessmentthataddressSDinbroadterms,deliveryofcapacity buildingmayfallshort \\
& $\begin{array}{l}\text { Moreeffectivetoolswouldestablishthedegreeofsuccessofinterventions } \\
\text { Focusescapacitybuildingactivitiesondifferentareasbutwithoutsupportfor championsandinfrastructure, } \\
\text { projectsmaybe “one-offs" }\end{array}$
\end{tabular}

\begin{abstract}
Portugalhasbeenslowtoengage with thesustainabilityagendaand thuscapacity buildingexamples arefew, andelicitingdatawasthereforemorechallenging.

The universities sampled in Brazil and Germany demonstrate different approachestobuildingcapacity,someofthemhavebeen moreinvolvedinprojects with the community than others; the Brazilian examples involve a number of projects with a human development focus rather than a generic sustainable development focus. However, the intention is not so much to compare the countriesbuttoidentifytheextenttowhichtheiruniversitiesare

Providing direction in the development of capabilities related to sustainability. Most of the capacity building projects illustrated are concerned with local initiatives, have a specialist focus, and aim to address the needs of particular communities.

Leuphana University highlighted a potential example); there was no evidence of rigorousattemptstocapturebefore/aftermeasures.

This is hardly surprising given that many universities have concentrated their efforts on greening their estates, and have then fought hard to secure ESD within the curriculum. This might mean that they have so far given less attention to a more strategic endeavour to build capacity forsustainable development in their regional community.Itmayalsobethecasethatthisthirdareaof activityhashadlessprioritybut will be the next stage of a work-in progress. It is also understandable given the difficulties of monitoring and evaluating capacity building, highlighted (although notinthecontextofsustainabilityactions) byBrownetal. (2001):benchmarkingthe starting point isimportantifyou want to evaluate success but "before" and "after" measuresare challengingtocaptureandrequiretimeandresources.Brown
\end{abstract}

Even though the sample is too small to allow results to be extrapolated to each country researched, these trends are symptomatic of the need for a more systematic approachtolink universitiesandlocalcommunitiesinrespectofcapacitybuilding for sustainable development. As Northmore and Hart (2011) point out, universities throughout the world need to more actively demonstrate the added value they bring when addressing complex social problemsin partnership withlocal communities; a morecoordinatedapproachmightsupportgreaterengagement.

Nevertheless, a common trait can be observed across the generality of the cases: very often projects related to capacity building originate as individual projects (the few exceptions lie within UK institutions). Such projects are frequently led by individualsorsmallgroupsofstaffandarenotnormallydriven centrallybutareoften inspiredbyindividualacademicinterests. Assuch theymayendeitherwhenfunding sourcesdecline, or when theindividualprojectchampionmoveson, orlosesinterest. Afurthercommonalityacross thesampledinstitutions(again with asmallexception in the UK) is that there is generally a lack of evaluation of programmes and implementation.

Even within those institutions within the UK where projects seem more substantial and are specifically related to sustainable development, evaluative measuresareintheformativestagesof development. Thereisverylittleevidencethat such activities are fully captured or centrally coordinated; they are unlikely to be systematicallyevaluated.BeingpartofaUNRCEmeansthatthere islikelytobemore capacity building activity but it does not necessarily follow that RCEs have greater impact,orbetter evaluationmeasures. Eveninthoseinstitutionswhereevaluation of capacity building was on the agenda, respondents were in the early stages of developing measures to evaluate their efforts; many suggested that they were strugglingtocomeupwithsufficiently robustmeasures. Themajorityofinstitutions havenoteven 1 considered addressing this area of activity.

\title{
Typicalmeasurescurrentlydeployedinclude:
}

Case study descriptions of projects (the most common measure). Number of student/staffhours.

Number of community stakeholders/participants involved (often recorded as attendanceatevents).

Specific indicators (reporting the project results). Behaviour changing(qualitativeapproach).

Noneoftheinstitutionsthatrespondedofferedanythingmore sophisticatedatthis point. There wasnoexplicitevidence of longitudinalstudies(although in Germany,

etal.(2001)usefully draw attention to the

difficulties:capacity andcapacitybuildingare

neverstatic;itisdifficulttocapture meaningful

data,toknowwhattomeasure(giventhe

multidimensionalnature); developmentoccurs

instageswithamultitude ofenvironmentaland

contextualfactorsthatinfluenceboth capacity

andperformance; effectsarenotfully

understoodand capacitymayactuallydecline

(Brownetal.,2001,p.37).Such complexities

mightbepartiallyresponsiblefortheapparent

deficit.

Further,although someofthelackofmonitoring and evaluation evidenced in the sampled institutions, lies within the methodological challenges, in large measure it alsorelatestothelackof acentralisedfunctionwithinuniversitiestocapturetherange of activities that individual academics engage with across the community. Thisalso offers a partial explanation as to why eliciting data for this study was difficult. The complicated nature of universities' engagement with stakeholders at a variety of levelsmeans thatitisunlikelythatinstitutions will havean overview of what isgoing on. Regarding the latter, knowing who is interacting with whom in the external environment, becomes an almost impossible task without good knowledge management andinformationsystems.

Institutional barriers contribute to the lack of monitoring and evaluation of capacity building. Some obstacles include a lack of interest and institutional commitment; absence of adequate resources for monitoring (mostly financial and human resources); lack of knowledge about how to monitor and evaluate capacity building(typesofapproachesandmethodologies); andthenature ofengagementwith stakeholdersandpartners.

Theevaluation of capacitybuildingisthus, quiteachallenge; universitiesneedto determine how they intend to measure the change and consider this in the context of timeandresources available. Whereresourcespermitablendoftools, methodologies and approaches, should be deployed toprovideapicture of what is changing(ornot). Also, findings should be triangulated by involving different stakeholders in the evaluationprocesses (Simister\&Smith,2010).

Table3 outlinessomeofthevariablesthatappeartoinfluence capacitybuildingfor sustainabledevelopmentatuniversities.

Very fewinstitutions developstaffcapabilityin partnership work, orcapturethe multiplicity of partnerships in play, that might build capacity; very few institutions havethestructuresand enablingplatformstoenhancedialoguewiththecommunityto collaborateincapacitybuilding, atthispointintime. 


\section{Lessonslearned}

In terms of lessons learned, evaluating universities' contributions to sustainable development in areas that move beyond campus greening and curriculum developmenttoembrace externaleffortstobuildsustainablecommunities, presentsa number of challenges. Institutions themselves have paid very little attention to capturingthemultiplewaysthatstaffinteractwith externalstakeholdersingeneral,let alonewithspecificregardto sustainabledevelopmentandinitiativestobuildexternal capacity.

Justasthereisnosinglerecipeormodel tofostersustainability incountriesand onehas totakeintoconsiderationacountry's politicalsetting on theonehand, and thedifferentprioritiesgiven tosustainabilityinhighereducationontheother, there is also no single way that academics engage with capacitybuilding. In addition, since within countries the institutional level of emphasis on sustainability varies considerably, it is not possible to generalise about how higher education is contributingtowardssustainable developmentthroughcapacitybuilding.

Evaluative measures do not generally exist at the institutional level for assessing overall the impact of building capacity; at the project level outputs are oftenrepresentedbycasestudies, evaluativemeasuresarelargelyin theformative stageswhich, in part,reflectsthemethodologicalchallenges of theconcept. Thus, capturingdatatogainmorethanadescriptiveoverview of universities' initiatives isdifficult.

The construction of a benchmarking instrument containing a set of good practices that would promote capacity building towards sustainability might be helpful.Thisinstrumentshould includeasetofmeasurestoevaluatedifferenttypes ofengagement whichasastarting pointmaysimply involvecrudemeasures such as,numberofactivities, numberofevents,numberofsupported projects, etc.

Finally, one of the lessons learned from this paper is the perceived need to documentandpromotecountriesexperiences, sothatdevelopmentsovertimecan be monitored, and assessments made as to whether improvements within the community tookplace(ornot).

\section{Conclusions}

This paper has argued that building sustainable communities is an important aspect of achieving sustainable development. Evaluation and programme planning on sustainable development are thus of great relevance. Universities have a key role to play within communities to engage with stakeholders and to contribute to capacity building, as demonstrated in the PROSPER (promoting School-community-university PartnershipstoEnhanceResilience) partnership model referred by Spoth et al. (2004), and in the University of Brighton's Community-University Partnership Programme (CUPP) presented by NorthmoreandHart(2011)andHart etal.(2009).

Even though a much larger sample would be needed to allow definitive conclusions, the responses collected from institutions across four countries demonstrate that although there are a variety of projects that are undoubtedly contributing to capacity building, these are largely ad hoc, and most are not effectively evaluated. A partial explanation (although not directly related to external capacitybuilding)issuggestedbyShriberg(2002):mostassessmenttools do not afford mechanisms for comparing campus efforts and most valuations neglectwhyinitiativesbeganandare kept.

Capacitybuildingwithincommunities(externallyfacing projects)appearsto have lagged behind universities' internally focused initiatives such as campus greening and seeking to embed ESD within the curriculum. Those universities, particularlywithin the UKwhohavemadeastrategic commitment to sustainable developmentandwhoalreadyhavehighlyregardedgreen credentials, arelikelyto bedoingmore externallybutmaynot necessarilyhaveaco-ordinatedapproach to capacitybuilding. Further, measures for evaluation and programmeplanning on sustainabledevelopmentwithafocusoncapacitybuilding, ifthey existatallarein theearlystagesofdevelopment.

Theresultssuggesttheimportanceofmanagementand informationsystemsto capture initiatives, as well as strong leadership to co-ordinate capacity building activities. Universities should ensure that skilled and adequate technical and human resourcesaredeveloped toguaranteethat therightcollaborative learning skills are nurtured and that enabling platforms are developed to facilitate collaboration.Additionally, acontinuous dialoguewithcommunitystakeholders andgovernment(localand national)isalsocrucialtofeedinvestmentintoprojects aimed at capacity building between HEIs and community and to support collaborations. This is necessary because, as Berke and Conroy (2000) suggest, plannersresponsibleforengagementmayhave onlyasuperficialunderstandingof how to translate the concept into practice, and interest groups may be sceptical aboutthe outputsofcapacitybuilding.

In the future if universities are to maximise their contribution towards sustainable development, it will be important to expand their externally facing efforts to build capacity for sustainable development within local communities. Future research needs to consider how to capture and develop synergy from the range of activities and approaches that individual academics undertake and to developtoolstocaptureimpactsbutalsotoconsiderhowto morecriticallyevaluate processes. Atthesametime, itwouldbe usefultomeasuretheextenttowhich these projectscontributeto researchwithinuniversities(andarevaluedassuch), aswell asthe extenttowhichtheyenhancelearningandpracticewithin communities.

More sophisticated measures to evaluate capacity building are undoubtedly needed but within the consideration that the need to enhance capacity for sustainabledevelopmentisanurgentissue; toomuchtimespentonmeasuresmay mean less time spent on actions. What seems more important at this time is to develop understanding further of the processes that secure the greatest engagement and the highest perceived positive outcomes. Further case study research should aim to show how enabling mechanisms, human resource development and particular processes, support collaborative learning for sustainability within communities. Universities have a critical role to play in contributing to sustainable development; they will fall short in that role if they do not prioritise learning with community stakeholders and contributing to local changeforsustainabledevelopment.

\section{References}

Alter,T.(2005).Achievingthepromiseofpublicscholarship.InS.Peters, N.Jordan, M.Adamek, \& T.Alter(Eds.),Engagingcampusandcommunity: Thepracticeof publicscholarshipinthestate andland-grantuniversitysystem(pp.461-487). Dayton:KetteringFoundation.

Barlett,P.F.,\&Chase,G.W.(2013).Sustainabilityinhighereducation:Storiesand strategiesfor transformation.Cambridge,MA:TheMITPress.

Brandli,L.L.,LealFillho,W.,Frandoloso,M.A.L.,Korf,E.,\&Daris,D.(2015).The environmental sustainabilityofBrazilianuniversities:Barriersandpreconditions. InW.LealFilho,U.M. Azeiro,S.Caeiro,\&F.Alves (Eds.),Integrating sustainabilitythinkinginscienceand engineeringcurricula(pp.63-74).New York: Springer.

Berke,P.R.,\&Conroy,M.M.(2000).Areweplanningforsustainabledevelopment? JournaloftheAmericanPlanningAssociation,66(1),21-33.http://dx.doi.org/ $10.1080 / 01944360008976081$

BournemouthBoroughCouncil(2014).Theearthcharter.Retrievedfromhttp:// www.bournemouth.gov.uk/Environment/GoGreenBournemouth/Earth-Charter/ The-EarthCharter.aspx

Brown,L.,LaFond,A.,\&Macintyre,K.(2001).Measuringcapacitybuilding.Carolina Population Center,UniversityofNorthCarolinaatChapelHillRetrievedfrom http://www.cpc.unc.edu/measure

CRE-Copernicus(1994).COPERNICUS-TheUniversityCharterforSustainable Development Retrievedfromhttp://www.iau-hesd.net/sites/default/files/ documents/copernicus.pdf

Davison,A.,Brown,P.,Pharo,E.,Warr,K.,McGregor,H.,Terkes,S., etal.(2014). Distributed leadershipbuildingcapacityforinterdisciplinaryclimatechange teachingatfouruniversities. InternationalJournalofSustainabilityinHigher Education, 15(1),98-110. http://dx.doi.org/10.1108/IJSHE-10-2012-0091

Delakowitz,B.,\&Hoffmann,A.(2000).TheHochschuleZittau/Go“rlitz.International Journalof SustainabilityinHigherEducation, 1(1),35-47.

Hart,A.,Northmore,S.,Gerhardt,C.,\&Rodriguez,P.(2009).Developing accessbetween universitiesandlocalcommunitygroups: Auniversity helpdeskinaction.JournalofHigher EducationOutreachandEngagement, 13(3),45-59.

Higgins,P.,Nicol,R.,Somervell,D.,\&Bownes,M.(2013).Thestudentexperience: Campus, curriculum, communitiesandtransitionatEdinburgh.InS. Sterling,L. Maxey,\&H.Luna(Eds.), Thesustainableuniversity:Progressandprospects(pp. 192-210). Oxon:EarthscanfromRoutledge.

LealFilho,W.(Ed.).(1998).UmweltschutzundNachhaltigkeitanHochschulen. Frankfurt:VerlagPeterLang.

LealFilho,W.(Ed.).(2010).Sustainabilityatuniversities:Opportunities, challengesand trends Frankfurt:PeterLangScientificPublishers.

Lozano,R.,Lukman,R.,Lozano,F.J.,Huisingh,D.,\&Lambrechts,W.(2011). Declarationsfor sustainabilityinhighereducation:Becomingbetterleaders throughaddressingtheuniversity system. JournalofCleanerProduction, 48,10 19.http://dx.doi.org/10.1016/j.jclepro.2011.10.006

Luna,H.,\&Maxey,L.(2013).Towardsagreenacademy. InS. Sterling,L.Maxey, \& H.Luna(Eds.), The sustainableuniversity:Progressandprospects(pp.281-303). Oxon:EarthscanfromRoutledge.

Merino,S.S.,Carmenado,I.,\&delos,R.(2012).Capacitybuildingindevelopment projects.ProcediaSocialandBehavioralSciences,46,960-967.http:// dx.doi.org/10.1016/j.sbspro.2012.05.231 
Moore,J.(2005).Sevenrecommendationsforcreatingsustainabilityeducationat theuniversitylevel:A guideforchangeagents. InternationalJournalof SustainabilityinHigherEducation,6(4),326332.http://dx.doi.org/10.1108/ 14676370510623829

Nicolaides,A.(2006).Theimplementationofenvironmentalmanagementtowards sustainable universitiesandeducationforsustainabledevelopmentasan ethicalimperative. International JournalofSustainabilityinHigherEducation,

7(4),414-421.http://dx.doi.org/10.1108/14676370610702217 Northmore,S.,\&Hart,A.(2011)

Sustainingcommunityuniversitypartnerships. Gateways:InternationalJournalofCommunity

ResearchandEngagement,4,1-11. http://dx.doi.org/10.5130/ijcre.v4i0.2356

O’Rafferty,S.,Curtis,H.,\&O'Connor,F.(2014).Mainstreamingsustainabilityin designeducation-A capacitybuildingframework. InternationalJournalof SustainabilityinHigherEducation, 15(2), 169-187.http://dx.doi.org/10.1108/ IJSHE-05-2012-0044

Raghubansie,A.,Corbett,C.,Boom,K.,\&Weaver,L.(2015).Digitallearningfor sustainability:An interactivemagazineforstudents, academicsandexpert practitioners.InW.LealFilho,L.L. Brandli,O.Kusnetsova,\&A.M.F.doPac,o (Eds.),Integrativeapproachestosustainable developmentatuniversitylevel:

Makinglinks(pp.3-18).NewYork:Springer

Schmitz,C.L.,Stinson,C.H.,\&James,C.D.(2010).Communityandenvironmental sustainability: Collaborationandinterdisciplinaryeducation.CriticalSocial Work,11(3),83-100.Retrieved fromhttp://www.uwindsor.ca/ criticalsocialwork/sites/uwindsor.ca.criticalsocialwork/files/coates_6_pdf

Scott,W.(2012).WhateverhappenedtotheRCEs?.Retrievedfromhttp://blogs.bath. ac.uk/edswahs/2012/10/19/whatever-happened-to-the-rces

Shiel,C.,\&Pac,o,A.(2012).Theimpactofuniversitypoliciesforsustainable developmentonstudents: Acomparisonofstudentsfromtwoinstitutions, one intheUKandoneinPortugal.InW.LealFilho (Ed.),Sustainabledevelopmentat universities:Newhorizons(pp.575-586).Frankfurt:PeterLang Scientific Publishers

Shriberg,M.(2002).Institutionalassessmenttoolsforsustainabilityinhigher education:Strengths, weaknesses, andimplicationsforpracticeandtheory. InternationalJournalofSustainabilityin HigherEducation,3(3),254-270.http:// dx.doi.org/10.1108/14676370210434714

Simister,N.,\&Smith,R.(2010).Monitoringandevaluating capacity building:Is itreallythatdifficult? International NGO Training and Research Center Retrieved from http://www.intrac.org/data/files/resources/677/Praxis-Paper-23-

Monitoring-and-Evaluating-Capacity-Building-is-it-really-that-difficult.pdf

Spoth,R.,Greenberg,M.,Bierman,K.,\&Redmond,C.(2004).PROSPERcommunity university partnershipmodelforpubliceducationsystems:Capacity-building forevidence-based, competence-buildingprevention.PreventionScience,5(1), 31-39.http://dx.doi.org/10.1023/B:PREV.0000013979.52796.8b

Thomas,I.,\&Day,T.(2014).Sustainabilitycapabilities,graduatecapabilities, and Australianuniversities. InternationalJournalofSustainabilityinHigherEducation, 15(2),208-227.http://dx.doi.org/10.1108/JJSHE-05-2012-0046

Tilbury,D.(2011).Educationforsustainabledevelopmentanexpertreviewof processesandlearning Paris:UNESCO.

Tilbury,D.(2012).Highereducationforsustainability:Aglobaloverview of commitmentandprogress. InHigherEducationintheWorld4.Higher Education'sCommitmenttoSustainability:From UnderstandingtoAction.GUNi SeriesontheSocialCommitmentofUniversities. GreatBritain CPIWilliam Clowes.

UNEP(2002).Capacitybuildingforsustainabledevelopment:AnoverviewofUNEP environmental capacitydevelopmentinitiatives. Retrievedfromhttp://www.unep org/Pdf/Capacity building.pdf

UnitedNations(2012).Resilientpeople,resilientplanet:Afutureworthchoosing.New York:UnitedNationsRetrievedfromhttp://uscib.org/docs/ GSPReportOverview_A4\%20size.pdf

UniversityofManchester(2013).Universitylivinglabforsustainability.Interim report.Retrievedfrom http://static.universitylivinglab.org/sites/default/files/ ll-interim-report.pdf

UniversityofManchester(2014).Retrievedfromhttp://universitylivinglab.org/.

UniversityofWales(2013).Strategicplan.Retrievedfromhttp://www.uwtsd.ac.uk/media/uwtsdwebsite/content-assets/documents/inspire/Strategic-Plan — FINAL-AGREED-version-7Nov-13.pdf

UniversityofWorcesterStrategicPlan,2013-2018(n.a.).Retrievedfromhttp:/ www.worcester.ac.uk/documents/university-worcester-strat-plan-2013-18.pdf.

UniversityofRostock(2014). SustainableUniversityRostock.Retrievedfromhttp:// www.unirostock.de/en/about-us/sustainable-university/

vanWeenen,H.(2000).Towardsavisionofasustainableuniversity. International Journalof SustainabilityinHigherEducation, 1(1),20-34.

Wade,R.(2013).Promotingsustainablecommunitieslocallyandglobally:Therole ofRegional

CentresofExpertise(RCEs).InS.Sterling,L.Maxey,\&H.Luna (Eds.), Thesustainableuniversity: EarthscanfromRoutledge. Progressandprospects(pp.89-109).Oxon:

WRI(2008).Worldresources2008:Rootsofresiliencegrowingthewealthofthepoor. Washington, DC:WorldResourcesInstituteincollaborationwithUnited NationsDevelopmentProgramme, UnitedNationsEnvironmentProgramme, andWorldBankRetrievedfrom http://www.wri.org/sites/default/files/pdf/ world resources 2008 roots of resilience.pdf 